\title{
O DESENVOLVIMENTO DE POLÍTICAS PÚBLICAS ATRAVÉS DA PARTICIPAÇÃO DA SOCIEDADE CIVIL
}

\author{
Rony Klay Viana de Freitas ${ }^{1}$ \\ Instituto Nacional do Seguro Social (INSS), Brasil
}

\begin{abstract}
Resumo.- Durante a maior parte da história, foi desenvolvida a idéia de que os governos devem formular políticas sociais para proporcionar o bem-estar dos seus cidadãos. O princípio de responsabilidade dos estados para assegurar o bem-estar destes erodiu consideravelmente. Movimentos políticos têm promovido a participação da comunidade como uma alternativa efetiva à do bem-estar assegurado pelo governo. Acredita-se que as comunidades locais têm potencial para organizar-se coletivamente se forem emancipadas do Estado, supostamente opressor e manipulador. Esse artigo tem o objetivo de apresentar alternativas viáveis ao desenvolvimento das políticas públicas com a participação da sociedade civil, visto a evidente crítica à participação do Estado nos assuntos do bem-estar social.
\end{abstract}

Palavras-chave.- administração pública; política Social; desenvolvimento sustentável

O Estado nunca havia desempenhado antes um papel relativamente importante no bem-estar social. Ao contrário de períodos históricos anteriores, quando em geral os governos mostravam-se pouco interessados em assuntos de bem-estar, os estados modernos utilizaram os poderes legislativos para criar programas de serviço social, formular políticas e planos sociais, regulamentar atividades que incidem no bem-estar humano e redistribuir recursos.

Especulou-se muito sobre as razões desta evolução, porém não foi aceita nenhuma explicação teórica da crescente participação governamental na área da assistência social.

Durante muito tempo, os serviços sociais governamentais contavam com o amplo apoio das pessoas comuns que recebiam seus benefícios, bem como de

\footnotetext{
${ }^{1}$ Pós-Graduado em Gestão Pública pela Faculdade Juvêncio Terra. Docente da Faculdade de Tecnologia e Ciências em Vitória da Conquista - BA. Técnico do Seguro Social no Instituto Nacional do Seguro Social, exercendo suas atividades na Seção de Recursos Humanos da Gerência Executiva em Vitória da Conquista
} 
dirigentes políticos. Porém os programas estatais de assistência começaram a experimentar dificuldades durante a década de 80 , no século passado. $O$ gasto em assistência social atingiu um nível sem precedentes, provocando o aumento da resistência pública à tributação. A inflação e a recessão enfraqueceram a economia de diversos países e tiveram um impacto negativo nos programas governamentais de assistência. Por conseguinte, os empréstimos globais, bem como o endividamento dos países em desenvolvimento, aceleraram e limitaram ainda mais os gastos em matéria social.

Não é possível afirmar que as críticas dirigidas ao Estado carecem de fundamento. O mau uso do poder estatal e a forma em que ele é exercido são do conhecimento de todos. Também não é possível negar que muitas vezes os programas estatais são ineficientes, caros e alheios às necessidades e aspirações da comunidade local.

$\mathrm{Na}$ medida em que os serviços sociais oferecidos pelo Estado começaram a ser questionados, enfoques alternativos ganharam maior popularidade, tais como a participação da comunidade e a proposta de responsabilidade da mesma pelo seu próprio bem-estar. Tal como assente Ihering (2001, p. 27):

Todos os direitos da humanidade foram conquistados pela luta; seus princípios mais importantes tiveram de enfrentar os ataques daqueles que a eles se opunham; todo e qualquer direito, seja o direito de um povo, seja o direito do indivíduo, só se afirma por uma disposição ininterrupta para a luta... O direito é um trabalho sem tréguas, não só do Poder Público, mas de toda a população.

Mediante o desenvolvimento da comunidade, a população e o governo conjugariam seus esforços para a melhoria da qualidade de vida da população.

Porém, existe um grande número de pessoas que defende a participação comunitária separadas do patrocínio governamental. $\mathrm{Na}$ verdade, alguns consideram que é preciso resistir a toda participação externa, e que as comunidades devem encontrar soluções para os seus próprios problemas.

Outros acreditam que as comunidades locais devem buscar assistência externa de organizações não-governamentais, que na sua opinião são progressistas, estão comprometidas com os ideais de participação, possuem maior flexibilidade em sua administração e estão livres das inibições de normas e regulamentações burocráticas.

Leal (2000), defende que:

... o Estado Social de Direito não vai conseguir responder, adequadamente, às demandas de participação efetiva e cotidiana da cidadania, na definição de políticas públicas e prioridades políticas emergentes, exigindo-se outras formas de 
viabilização e compromisso com a Sociedade. Daí, surge a necessidade de readequação do Estado e do Governo à nova era, valorando, ainda mais, o conteúdo efetivamente democrático das instituições públicas representativas e, quiçá, criando outras novas.

Naturalmente, também existem aqueles que afirmam que as comunidades locais devem tratar de explorar os recursos do Estado. Eles se opõem à idéia de que o apoio estatal deva ser rejeitado, e afirmam que as comunidades locais devem negociar para obter ajuda do Estado como apoio aos seus esforços rumo ao desenvolvimento. No entanto, estimam que estes recursos devem estar assegurados sem permitir que o governo exerça o controle sobre os mesmo, já que esta situação conduz invariavelmente à subversão da sua autonomia.

Afirmar que as comunidades locais podem organizar-se de forma espontânea para melhorar significativamente suas condições sociais e econômicas é pouco provável e não é produtivo. É injusto esperar que setores carentes da comunidade se abasteçam independentemente de toda forma de ajuda externa, e é pouco provável que realmente possam fazê-lo.

O conceito de que as organizações não-governamentais oferecem uma alternativa viável ao apoio estatal é mais produto de um pensamento ideológico do que de um sistemático. Apesar da sua significativa contribuição, o setor voluntário apresenta numerosas deficiências. Não está provido de organização burocrática e financeira de forma permanente, e nem sempre está comprometido fundamentalmente com a satisfação das necessidades da população. Embora as organizações voluntárias atualmente tenham acesso à assistência, sua capacidade de assegurar recursos não pode ser comparada com a do Estado, além do que não é possível assegurar qual será o seu tempo de sobrevivência, visto que a maioria dessas organizações vivem de doações e/ou parcerias.

Seria benéfico que as comunidades locais fizessem uma avaliação mais realista do papel do Estado no desenvolvimento social, bem como uma apreciação mais positiva de sua potencial contribuição aos esforços da comunidade. É possível fazer uma síntese, onde os papéis respectivos do Estado, da comunidade e dos setores voluntários, seriam levados em consideração, através de uma análise dos pontos fortes e fracos de cada um destes setores.

É possível se desenvolver estratégias para harmonização dos três setores, primeiramente inclui-se a criação de órgãos consultivos, a introdução de procedimentos formais obrigatórios de consulta entre funcionários e comunidades locais, a criação de cursos de capacitação para a participação tanto para servidores públicos como para membros da comunidade e o estabelecimento de procedimentos para avaliar o apoio estatal.

Através destas primeiras estratégias as comunidades poderão conhecer mais profundamente a estrutura social e sua própria localização na mesma, mediante um processo de conscientização. Elas seriam incentivadas a aprender táticas de negociação política e a desenvolver confiança em suas atuações com as organizações governamentais. A partir desta perspectiva, as comunidades locais 
estariam mais fortalecidas em sua relação com o Estado, e pode incrementar seu bem-estar e adquirir maior controle sobre os assuntos a elas vinculados.

O êxito disso não depende apenas de uma reorientação das burocracias estatais, mas também da criação nas pessoas da capacidade de organizar-se para o seu próprio desenvolvimento. O importante é criar consciência e motivação nas pessoas para que elas pensem que as coisas podem melhorar, que elas têm opções.

Através desses preceitos vemos que uma população motivada para enfrentar os seus próprios problemas, inicialmente a nível comunitário, pode organizar-se de forma mais efetiva a fim de atingir este objetivo, através de uma participação real do Estado e das organizações não governamentais.

\section{REFERÊNCIAS:}

(1980) BONAVIDES, Paulo. Do Estado Liberal ao Estado Social. Rio de Janeiro: Forense, 1980.

(1989) BUARQUE, Cristovam. Na Fronteira do Futuro. Brasília: Editora Universidade de Brasília, 1989.

(1994) KLIKSBERG, Bernardo (Org.). Pobreza: uma questão inadiável, novas propostas a nível mundial. Trad. Cláudia Schilling. Brasília: ENAP, 1994.

(2001) IHERING, Rudolf Von. A Luta Pelo Direito. Trad. Pietro Nassetti. São Paulo: Martin Claret, 2001.

(2000) LEAL, Rogério Gesta. Perspectivas Hermenêuticas dos Direitos Humanos e Fundamentais no Brasil. Porto Alegre: Livraria do Advogado, 2000.

(1988) PASOLO, César Luiz. Função Social do Estado Contemporâneo. Florianópolis: Estudantil, 1988.

(1994) ROCHA, Carmem Lúcia Antunes. Princípios Constitucionais da Administração Pública. Belo Horizonte: Del Rey, 1994. 